\title{
Effect of Growth Regulators, Carbohydrates and Antioxidant Compounds on Biomass, Flavonoid Accumulation and Enzyme Activity in Callus Cultures of Rumex vesicarius $\mathrm{L}$.
}

\author{
Nadia M. El-Shafey, Enas S. Ahmed, Mona Sayed*, Ola \\ Hammouda, S. A. Khodary \\ Department of Botany and Microbiology, Faculty of Science, \\ Beni-Suef University, Beni-Suef, Egypt.
}

\begin{abstract}
I N THE PRESENT study, growth regulators, sugars and antioxidants were investigated for their effect on callus growth, flavonoid content as well as the activity of some related enzymes in callus culture of Rumex vesicarius. The effect of Murashige and skoog media (MS) containing indole butyric acid (IBA), naphthalene acetic acid (NAA), or 2,4dichlorophenoxy acetic acid (2,4-D) on callus induction from cotyledonary leaf and hypocotyl explants was investigated. Results revealed that the highest callus biomass (fresh and dry weights) was obtained at $0.5 \mathrm{mg} \mathrm{l}^{-1}$ IBA using cotyledonary leaf explant. Both sucrose and fructose promoted a good callus dry mass, while the highest flavonoid content was enhanced with the medium supplemented with fructose. Citric acid was the best antioxidant in reducing the callus browning intensity and significantly inhibiting polyphenol oxidase (PPO) activity by $13.7 \%$. Citric acid also increased the callus dry weight by $26 \%$ and total flavonoid content by $67 \%$ over control. In conclusion, in vitro culturing of medicinal plant, Rumex vesicarius, enables increase of the biomass production and the yield of its biologically active constituents.
\end{abstract}

Keywords: Rumex vesicarius, Callogenesis, Sugars, Browning, Flavonoid.

Plant tissue culture provides a new aspect of nontraditional agriculture of medicinal plants. Recent research and technologies showed the possibility of utilizing tissue culture techniques in large scale production of naturally produced secondary metabolites. Rumex vesicarius L. is a wild winter medicinal plant. It has a wide range of biological and medicinal activities. Phytochemical studies revealed the occurrence of some important flavonoids, vitexin and orientin which

*Corresponding author: monasayed.science@ gmail.com 
are reported for their anticancer, hepatoprotection and protection against radiation hazards (Pandey and Madhuri 2010; Tan et al., 2012).

Previous studies have focused on the production of many secondary metabolites via callus culture (Ikenaga et al., 2000; Maheshwari et al., 2007 and Jain et al., 2012). Special interests toward callus flavonoids were reported by Wang et al. (2013) and Loredo-Carrillo et al. (2013). Establishment and optimization of the conditions of callus culture are considered as the initial and essential steps of in vitro production of secondary metabolites. Callus cultures could be used for the production of essential metabolites directly or through cell suspension cultures derived from them. In this context, growth regulators play essential role in various in vitro tissue culture techniques defining the time and percentage of culture induction and rate of culture development (Gaspar et al., 1996). Moreover, determination of the appropriate type and concentration of growth regulators enables obtaining maximum yield of the desired secondary products.

In plants, simple carbohydrates are primary metabolites that play essential role as vital sources of energy and carbon skeletons for more complex organic compounds including secondary products such as flavonoid. Sugars have been reported for their involvement in plant immunity and as signaling molecules (Sheen et al., 1999 and Rolland et al., 2006). As an example, sucrose induces isoflavonoids synthesis as a defense response against Fusarium oxysporum in lupine (Morkunas et al., 2005). These studies stand for the ability of some carbohydrates to affect the production of secondary metabolites in plant tissue. Factors responsible for the accumulation of secondary products may be via affecting the enzymes involved in their biosynthesis and metabolism. Phenylalanine ammonia-lyase (PAL) catalyzes the first step of the core pathway of general phenylpropanoid metabolism. Branch pathways lead to the formation of phenolic acids and polyphenols that have various functions in plants, notably in defense, such as cell wall strengthening and repair (e.g. lignin and suberin), and antimicrobial activity (isoflavonoids phytoalexins) (Hammerschmidt 1999). The resulting phenolics are often converted into more reactive by phenol oxidases and peroxidases (Mayer and Harel, 1979; Heath 1980). Stimulation of phenylalanine ammonia lyase synthesis by exogenous carbohydrates has been cited as a suggested mechanism by which they could influence the production of phenolic compounds (Zuckerg 1969).

In vitro production of callus tissue is commonly accompanied with the problem of callus browning caused by the accumulation of phenolic compounds followed by their oxidation (enzymatically and nonenzymatically). Callus browning (necrosis of callus tissue) comprises a serious problem and obtaining a healthy and fast growing callus culture is critical for study of in vitro elicitation of secondary metabolites and further large scale application. Citric acid was among various organic substances with antioxidant properties that have been reported as antibrowning agents (Ndakidemi et al., 2014 and Mathews, 1987 and Anthony et al., 2004). In addition sodium thiosulphate was known for its Egypt. J. Bot., 56, No. 3 (2016) 
antioxidant capacity while polyvinylpyrrolidone (PVP) is an adsorbent of phenolic compounds (Sathyanarayana and Varghese, 2007).

Our study aims to evaluate 1) the effect of growth regulators on induction, growth and flavonoids content in callus of Rumex vesicarius; 2) the effect of sugars and antioxidants on biomass, flavonoid content and the activity of PAL, polyphenol oxidase (PPO) and peroxidase (POX) in callus of $R$. vesicarius. The contribution of antioxidants to reduce callus browning is also studied.

\section{Materials and Methods}

In vitro seeds germination

Seeds of Rumex vesicarius were collected from the coastal region nearby Agiba beach, Marsa Matrouh governorate, Egypt at April 2012. Seeds were surface sterilized by $70 \%$ ethanol for 60 seconds followed by $40 \%$ commercial bleach (Clorox containing 5\% sodium hypochlorite) for $15 \mathrm{~min}$. The seeds were rinsed three times, under aseptic condition, with sterile distilled water. The surface-sterilized seeds were germinated in baby food on a germination medium, with approximately 5 seeds per jar. The germination medium contained fullstrength MS basal medium (Murashige and Skoog, 1962), solidified with $8 \mathrm{~g} \mathrm{l}^{-1}$ agar. The seeds were placed in refrigerator for enhancing germination process. Once the radicle emerged, the germinated seeds were transferred to growth chamber at temperature $25 \pm 2{ }^{\circ} \mathrm{C}$ and $16 \mathrm{hr}$ photoperiod.

\section{Establishment of callus culture}

Callus culture was initiated from both cotyledonary leaf and hypocotyl of 15 days old seedlings of Rumex vesicarius. About $5 \mathrm{~mm}$ explant segments were cultured on MS basal medium supplemented with $30 \mathrm{~g} \mathrm{l}^{-1}$ sucrose and various concentrations $\left(0.5,1\right.$ and $\left.2 \mathrm{mg} \mathrm{l}^{-1}\right)$ of 2,4-D, NAA or IBA were added. The $\mathrm{pH}$ of the media was adjusted to $5.8-6$ using $1 \mathrm{~N} \mathrm{NaOH}$ and $1 \mathrm{~N} \mathrm{HCl}$. The media were solidified with $8 \mathrm{~g}^{-1}$ agar prior to autoclaving at $121^{\circ} \mathrm{C}$ and 15 psi for $20 \mathrm{~min}$. Cultures were incubated in darkness at $25 \pm 2{ }^{\circ} \mathrm{C}$. Calli were collected after 4 weeks and their fresh weights were recorded. The dry weight was determined after oven drying at $60{ }^{\circ} \mathrm{C}$ and the dry samples were maintained for estimation of total flavonoid.

Effect of carbohydrates on callus biomass

About $0.5 \mathrm{~g}$ callus (5 weeks old) was inoculated on MS basal media fortified with $30 \mathrm{~g} \mathrm{l}^{-1}$ of one of the investigated sugars (sucrose, glucose, fructose, galactose and mannose) and $0.5 \mathrm{mg}^{-1}$ IBA. PH was adjusted at 5.8-6 and the media were solidified with $8 \mathrm{~g} \mathrm{l}^{-1}$ agar. The cultures were incubated in darkness at $25 \pm 2{ }^{\circ} \mathrm{C}$. After 15 days, biomass of the resulting calli was estimated as fresh and dry weights. Some of the fresh calli were preserved at $-20{ }^{\circ} \mathrm{C}$ for assaying 
enzymatic activity and the rest were oven dried at $60{ }^{\circ} \mathrm{C}$ for estimation of total flavonoid.

Effect of antioxidants on callus biomass, browning intensity and flavonoid accumulation

About $0.2 \mathrm{~g}$ of 5 weeks old calli was sub-cultured on MS basal media supplemented with $30 \mathrm{~g} \mathrm{l}^{-1}$ sucrose and $0.5 \mathrm{mg} \mathrm{l}^{-1}$ IBA. Sodium thiosulphate, citric acid or PVP were added to the culture media at a final concentration of $0.02 \mathrm{mM}$. Then, the media were adjusted at $\mathrm{pH}$ 5.8-6 and solidified with $8 \mathrm{~g}$ $1^{-1}$ agar. The inoculated cultures were incubated in darkness at $25 \pm 2{ }^{\circ} \mathrm{C}$. Control media were prepared as previously mentioned but without the addition of antioxidants. After 15 days, the degree of callus browning was recorded as $(+,++$ and +++$)$ and the calli were harvested. Callus biomass was determined as fresh and dry weights. Fresh and dry samples were maintained for analysis as previously mentioned.

\section{Estimation of total flavonoid}

Total flavonoid content was measured by the aluminum chloride colorimetric assay (Zhishen et al., 1999). Callus dry material was extracted with $80 \%$ aqueous methanol. One milliliter of callus extract or standard solution of quercetin $(0.01$ $0.07 \mathrm{mg} \mathrm{ml}^{-1}$ ) was mixed with $4 \mathrm{ml}$ distilled $\mathrm{H}_{2} \mathrm{O}$. Then, $0.3 \mathrm{ml}$ of $5 \% \mathrm{NaNO}_{2}$ was added and waited for $5 \mathrm{~min}$ followed by $0.3 \mathrm{ml}$ of $10 \% \mathrm{AlCl}_{3}$. After $6 \mathrm{~min}$, $2 \mathrm{ml}$ of $1 \mathrm{M} \mathrm{NaOH}$ solution was added and the total volume was made up to $10 \mathrm{ml}$ with distilled $\mathrm{H}_{2} \mathrm{O}$. Samples were replicated three times. The assay mixture was mixed well and the absorbance was determined at $510 \mathrm{~nm}$ against reagent blank. Total flavonoid content was expressed as $\mathrm{mg}$ quercetin equivalent $\mathrm{g}^{-1}$ dry weight.

\section{Extraction and estimation of total soluble protein}

Total soluble protein was determined following the method described by Bradford (1976) using Coomassie blue G250 reagent (Sigma aldrish, USA) and bovine serum albumin as standard. Fresh callus tissue $(0.5 \mathrm{~g})$ was frozen in liquid nitrogen, homogenized and extracted with $10 \mathrm{ml}$ of $100 \mathrm{mM}$ phosphate buffer $\mathrm{pH}$ 7. The homogenate was centrifuged at $6000 \mathrm{rpm}$ at $4^{\circ} \mathrm{C}$ for $30 \mathrm{~min}$. The supernatant was separated and used for estimation of total soluble protein and the assay of antioxidant enzymes as well.

Assay of Polyphenol oxidase activity

Activity of PPO (EC 1.10.3.1) was assayed following the method of Kar and Mishra (1976). Five $\mathrm{ml}$ of the assay mixture contained $30 \mathrm{mM}$ of phosphate buffer (pH 6.8), $0.5 \mathrm{mM}$ catechol and $1 \mathrm{ml}$ of crude enzyme extract. After incubation at $25^{\circ} \mathrm{C}$ for $10 \mathrm{~min}$, the reaction was stopped with the addition of $1 \mathrm{ml}$ of $10 \%$ sulfuric acid. The absorbance was measured at $430 \mathrm{~nm}$. The enzyme activity was expressed as $\mathrm{U} \mathrm{mg}^{-1}$ protein, where $\mathrm{U}=0.01$ change in absorbance $\mathrm{h}^{-1}$.

\section{Assay of peroxidase activity}

Peroxidase (EC 1.11.1.7) activity was assayed according to Kar and Mishra (1976). Five $\mathrm{ml}$ of the assay mixture containing $30 \mathrm{mM}$ of phosphate buffer (pH Egypt. J. Bot., 56, No. 3 (2016) 
6.8), $0.5 \mathrm{mM}$ catechol, $50 \mu \mathrm{M}$ of hydrogen peroxide and $1 \mathrm{ml}$ of crude enzyme extract. After incubation at $25^{\circ} \mathrm{C}$ for $10 \mathrm{~min}, 1 \mathrm{ml}$ of $10 \%$ sulfuric acid was added to stop the enzymatic reaction. The absorbance was measured at $430 \mathrm{~nm}$. The enzyme activity was expressed as $\mathrm{U} \mathrm{mg}^{-1}$ protein, where $\mathrm{U}=0.01$ change in absorbance $\mathrm{h}^{-1}$.

\section{Extraction and Assay of PAL activity}

A known weight of frozen callus tissue was powdered in liquid nitrogen by the help of chilled mortar and a pestle, then homogenized in $5 \mathrm{ml}$ of sodium borate buffer ( $\mathrm{pH} \mathrm{8.8)} \mathrm{containing} 1 \mathrm{mM}$ EDTA, $4 \%(\mathrm{w} / \mathrm{v}) \mathrm{PVP}$ and $2 \mathrm{mM} \beta$ mercaptoethanol. Then, it was centrifuged at $10000 \mathrm{rpm}$ for $10 \mathrm{~min}$ at $4{ }^{\circ} \mathrm{C}$. The supernatant (crude enzyme extract) was separated and stored at $-20{ }^{\circ} \mathrm{C}$ until the bioassay time. The activity of PAL (EC 4.3.1.5) in the crude enzyme extract was determined according to Cheng and Breen (1991). Three milliliters of the assay mixture contained $30 \mu \mathrm{mol} \mathrm{L}$-phenylalanine, $30 \mathrm{mM}$ sodium borate buffer $(\mathrm{pH}$ 8.8 ), and $0.5 \mathrm{ml}$ enzyme extract. The reaction was intiated by adding substrate. The reaction was stopped by addition of $0.1 \mathrm{ml} 6 \mathrm{~N} \mathrm{HCl}$ and the absorbance was measured at $290 \mathrm{~nm}$. The assay was performed in triplicate. The enzyme activity was expressed as $\mathrm{U} \mathrm{mg}^{-1}$ protein, where $\mathrm{U}=$ absorbance $\mathrm{h}^{-1}$.

\section{Statistical analysis}

The experiments were performed in triplicates, and subjected to one way analysis of variance (ANOVA). The significant differences among samples were determined by Duncan's multiple range test at $\mathrm{p}=0.05$ using SPSS v 16. All values were expressed as means of replicates (at least $n=3$ ) $\pm S E$

\section{Results}

Effect of growth regulators on callus induction, biomass and flavonoid accumulation

Callus appeared at the cut edges of inoculated explants after 10-12 days of culture. The obtained callus was compact and yellow in color but it quickly turned into brown. Both explants, cotyledonary leaf and hypocotyls, exhibited high percentage of callus induction (Tables 1 and 2). However, the results showed that explants from cotyledonary leaf were superior in callus induction and proliferation to those of hypocotyl. In most treatments, IBA was the best auxin that significantly scored the highest biomass, fresh and dry weights, of the callus derived from cotyledonary leaf as well as hypocotyls explant, compared with 2,4-D and NAA. Cotyledonary leaf explants induced maximum callus biomass $\left(0.852 \mathrm{~g}\right.$ fresh wt and $0.065 \mathrm{~g}$ dry wt) at low level of IBA $\left(0.5 \mathrm{mg} \mathrm{l}^{-1}\right)$. Nonetheless high level of the same auxin induced adventitious roots at the surface of the callus. 
TABLE 1. Effect of growth regulators on the biomass and flavonoid content of callus derived from cotyledonary leaf explant of Rumex vesicarius. values listed are average $(n=3-5) \pm S E$.

\begin{tabular}{|c|c|c|c|c|c|c|}
\hline \multicolumn{2}{|c|}{$\begin{array}{c}\text { Growth regulators } \\
\left(\mathbf{m g ~ I}^{-1}\right)\end{array}$} & $\begin{array}{c}\text { Callus } \\
\text { induction } \\
\text { \% }\end{array}$ & \multicolumn{2}{c|}{$\begin{array}{c}\text { Callus biomass } \\
\text { (g) }\end{array}$} & $\begin{array}{c}\text { Total flavonoid } \\
\text { content } \\
\left(\mathbf{m g ~ g}^{-1} \text { Dry wt }\right)\end{array}$ \\
\hline $\begin{array}{c}\mathbf{2 , 4 -} \\
\text { D }\end{array}$ & IBA & NAA & & Fresh weight & Dry weight & \\
\hline 0.5 & & & 100 & $0.322 \pm 0.032 \mathrm{a}$ & $0.021 \pm 0.000 \mathrm{a}$ & $3.30 \pm 0.05 \mathrm{~b}$ \\
\hline 1 & & & 100 & $0.319 \pm 0.021 \mathrm{a}$ & $0.024 \pm 0.001 \mathrm{a}$ & $1.98 \pm 0.11 \mathrm{a}$ \\
\hline 2 & & & 100 & $0.31 \pm 0.018 \mathrm{a}$ & $0.021 \pm 0.001 \mathrm{a}$ & $2.08 \pm 0.06 \mathrm{a}$ \\
\hline & 0.5 & & 100 & $0.852 \pm 0.094 \mathrm{c}$ & $0.065 \pm 0.008 \mathrm{c}$ & $12.2 \pm 0.34 \mathrm{f}$ \\
\hline & 1 & & 100 & $0.306 \pm 0.030 \mathrm{a}$ & $0.02 \pm 0.003 \mathrm{a}$ & $10.8 \pm 0.42 \mathrm{e}$ \\
\hline & 2 & & 100 & $0.611 \pm 0.051 \mathrm{~b}$ & $0.045 \pm 0.004 \mathrm{~b}$ & $12.9 \pm 0.14 \mathrm{~g}$ \\
\hline & & 0.5 & 100 & $0.353 \pm 0.036 \mathrm{a}$ & $0.022 \pm 0.002 \mathrm{a}$ & $5.07 \pm 0.09 \mathrm{~d}$ \\
\hline & & 1 & 100 & $0.322 \pm 0.015 \mathrm{a}$ & $0.021 \pm 0.001 \mathrm{a}$ & $5.34 \pm 0.16 \mathrm{~d}$ \\
\hline & & 2 & 88 & $0.26 \pm 0.028 \mathrm{a}$ & $0.016 \pm 0.000 \mathrm{a}$ & $4.11 \pm 0.03 \mathrm{c}$ \\
\hline
\end{tabular}

Values followed by the same letters are not significantly different $(\mathrm{P}=0.05)$.

The analysis of the callus derived from cotyledonary leaf showed that the applied growth regulators varied in their influence on the production of flavonoid. The highest flavonoid accumulation was recorded in calli cultured on IBA followed by NAA while, 2,4-D exhibited the lowest one. In most cases, increasing the concentration of corresponding phytohormone resulted in a significant decrease of flavonoid content (Table 1).

TABLE 2. Effect of growth regulators on the biomass of callus derived from hypocotyl explant of Rumex vesicarius. values listed are average $(n=5)$ \pm SE.

\begin{tabular}{|c|c|c|c|c|c|}
\hline \multicolumn{3}{|c|}{ Growth regulators $\left(\mathrm{mg} \mathrm{l}^{-1}\right)$} & \multirow[t]{2}{*}{ Callus induction (\%) } & \multicolumn{2}{|c|}{ Callus biomass (g) } \\
\hline 2,4-D & IBA & NAA & & Fresh weight & Dry weight \\
\hline 0.5 & & & 62 & $0.141 \pm 0.023 b c$ & $0.012 \pm 0.002 \mathrm{ab}$ \\
\hline 1 & & & 100 & $0.141 \pm 0.015 b c$ & $0.009 \pm 0.000 \mathrm{a}$ \\
\hline \multirow[t]{7}{*}{2} & & & 100 & $0.088 \pm 0.002 \mathrm{ab}$ & $0.006 \pm 0.000 \mathrm{a}$ \\
\hline & 0.5 & & 84 & $0.0599 \pm 0.015 \mathrm{a}$ & $0.007 \pm 0.001 \mathrm{a}$ \\
\hline & 1 & & 100 & $0.119 \pm 0.027 \mathrm{ab}$ & $0.012 \pm 0.003 \mathrm{ab}$ \\
\hline & 2 & & 100 & $0.179 \pm 0.023 c$ & $0.02 \pm 0.009 \mathrm{~b}$ \\
\hline & & 0.5 & 100 & $0.0814 \pm 0.009 \mathrm{ab}$ & $0.007 \pm 0.000 \mathrm{a}$ \\
\hline & & 1 & 100 & $0.100 \pm 0.025 \mathrm{ab}$ & $0.007 \pm 0.000 \mathrm{a}$ \\
\hline & & 2 & 100 & $0.082 \pm 0.017 \mathrm{ab}$ & $0.008 \pm 0.003 a$ \\
\hline
\end{tabular}

Values followed by the same letters are not significantly different $(\mathrm{P}=0.05)$.

Egypt. J. Bot., 56, No. 3 (2016) 
Effect of carbohydrates on callus biomass, flavonoid accumulation and enzymes activity

Sucrose was the most stimulatory sugar that induced the highest fresh wt, while galactose and mannose were the most inhibitory ones and produced highly intensed browning of callus (Table 3). Glucose and fructose came second to sucrose; however the former resulted in formation of adventitious roots. On the basis of dry weight, both sucrose and fructose (nonsignificantly different) brought about high biomass production ( 0.139 and $0.114 \mathrm{~g}$, respectively), while galactose and mannose induced low biomass.

Assaying of enzyme activities and flavonoids revealed that compared with most of the other investigated sugars, callus treated with fructose exhibited lower activity of antioxidative enzymes (POX and PPO; 22.0 and $4.93 \mathrm{U} \mathrm{mg}^{-1}$ protein, respectively), higher activity of PAL (2.69 $\mathrm{U} \mathrm{mg}^{-1}$ protein) and the high accumulation of flavonoids $\left(12.7 \mathrm{mg} \mathrm{g}^{-1}\right.$ dry wt). The highest accumulation of flavonoids in case of galactose was accompanied with high activity of POX, PPO and PAL. Glucose came the last among the investigated sugars by recording the lowest value of most of the investigated parameters (POX and PPO activities and flavonoid accumulation). Nonetheless, it imposed high PAL activity (Table 3).

Effect of antioxidants on callus biomass, browning intensity and flavonoid accumulation

Our results revealed that none of the investigated antioxidants significantly affected callus fresh weight. In contrast, the rest of the investigated parameters significantly responded to the evaluated antioxidants. Above all the treatments, citric acid significantly scored the highest accumulation of flavonoids that was accompanied with nonsignificant stimulation of PAL, significant inhibition of POX and PPO and consequently minimizing the browning intensity (Table 4 \& Fig. 1). Both sodium thiosulfate and PVP could not efficiently protect the callus from browning. Although sodium thiosulfate significantly increased dry weight, PAL activity and total flavonoids, besides inhibiting POX activity. It significantly enhanced the activity of PPO by $13 \%$ over control. PVP multiplied the activity of PAL by about two folds and imposed high flavonoid content, nonetheless it significantly stimulated PPO by $118 \%$ over control. 


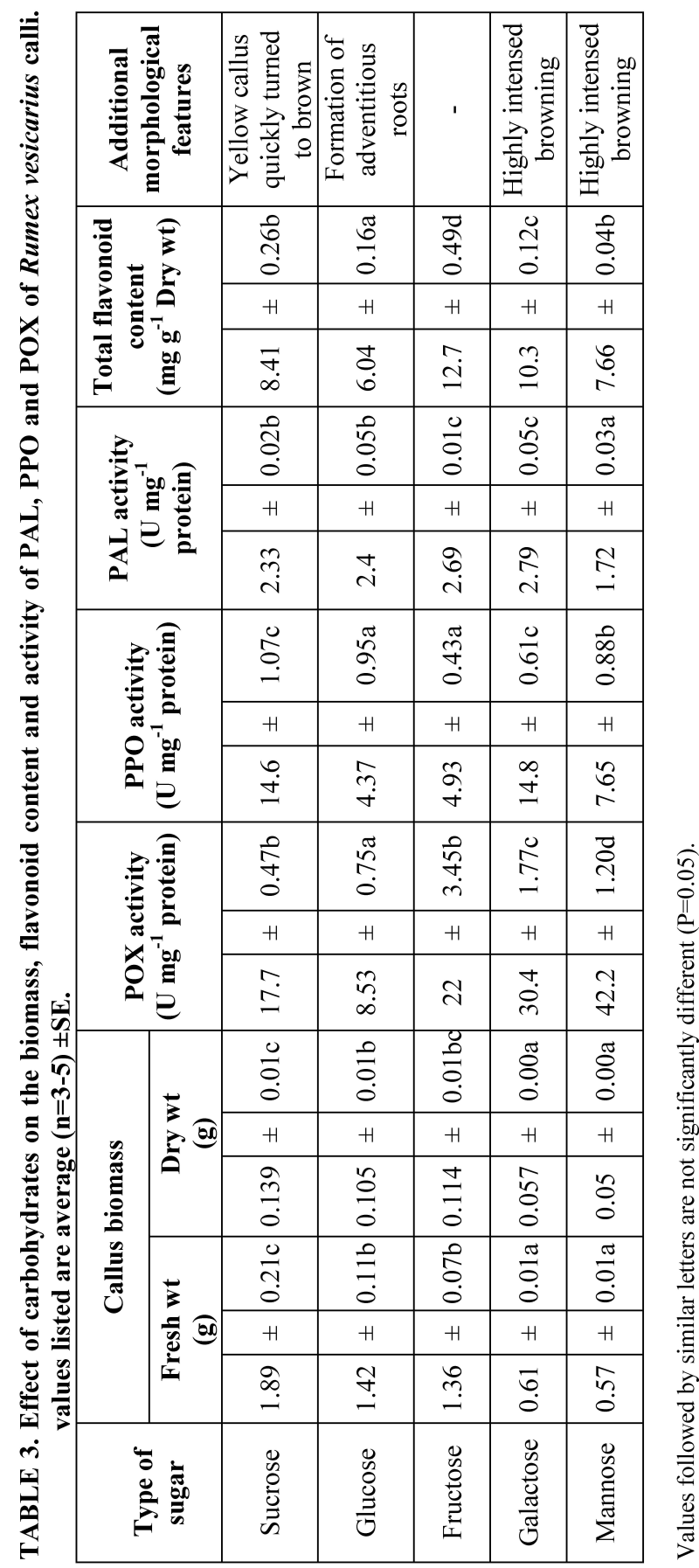

Egypt. J. Bot., 56, No. 3 (2016) 
EFFECT OF GROWTH REGULATORS, CARBOHYDRATES ...

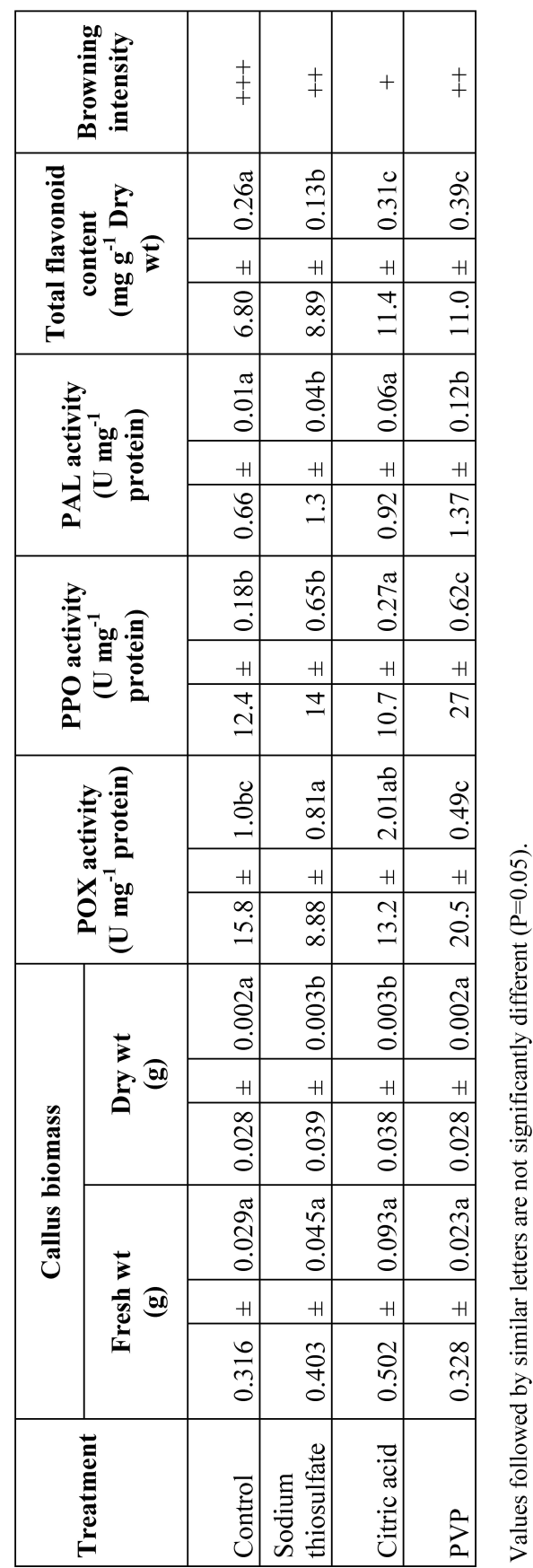

Egypt. J. Bot., 56, No. 3 (2016) 


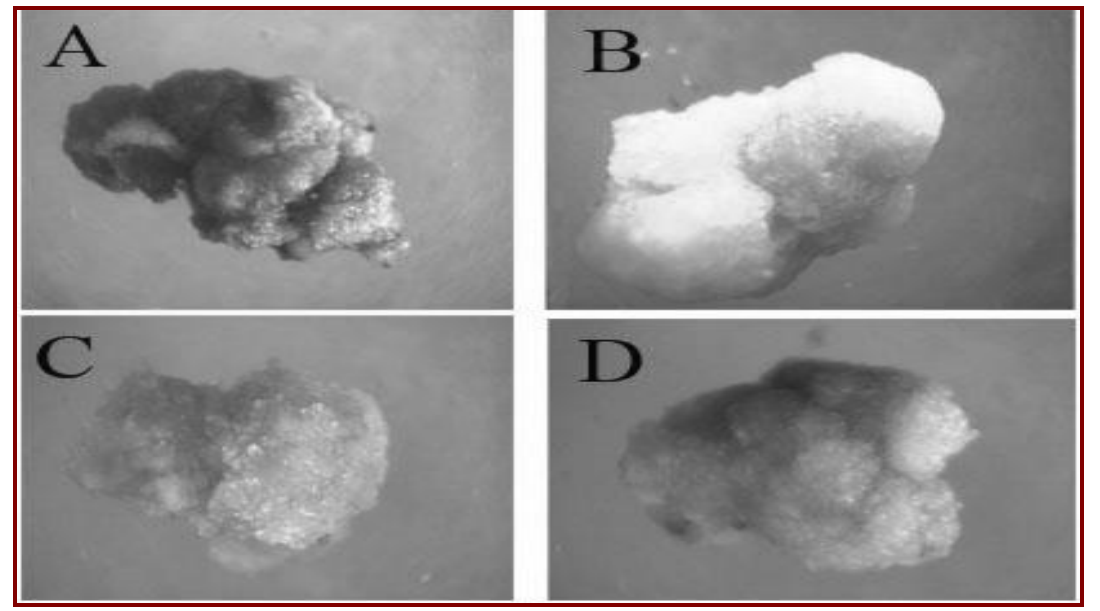

Fig. 1. Healing of callus browning by compounds with antioxidant activity A: control callus cultured on medium without antioxidant agent, B: callus treated with citric acid, C: callus treated with sodium thiosulfate and D: callus treated with PVP.

\section{Discussion}

Effect of growth regulators on callus induction, biomass and flavonoid accumulation

Callus cultures derived from medicinal plants are considered as raw materials and a good source of pharmaceutical and nutraceutical secondary metabolites. Effect of various phytohormones on in vitro callus induction and proliferation was extensively studied, but few studies were conducted regarding Rumex sp., particularly Rumex vesicarius.

Comparison between the explant types (cotyledonary leaves and hypocotyl) indicated that the response of cotyledonary leaf was better for callus initiation and biomass formation than hypocotyl explant. Many studies depended on leaf tissues as a suitable explant to induce embryogenic callus (Wang et al., 2011 and Giridhar et al., 2004) or nonembryogenic callus (Karam et al., 2003). Different tissues may have different levels of endogenous hormones and therefore, the type of explant source would have a critical impact on the callus induction and its regeneration success (Yan et al., 2009 and Das et al., 2013).

In the present study, the maximum callus proliferation was induced by $0.5 \mathrm{mg}^{-1}$ IBA using cotyledonary leaf explant. But, increasing the concentration of this phytohormone caused a delay of callus growth, since it was associated with the formation of adventitious roots from callus cells which resulted in lowering callus proliferation. On the other hand, 2,4-D and NAA (with various concentrations) were less effective in promoting callus biomass production in comparison with IBA despite they gave high callus induction. This may imply

Egypt. J. Bot., 56, No. 3 (2016) 
that both kinds of auxins were less favorable for callus productivity of the studied plant. Auxins are fundamental for the establishment of in vitro cultures (Catapan et al., 2002 and Pasqua et al., 2003), but concentration and combination of these plant growth regulators must be defined for each species (Loredo-Carrillo et al., 2013). Previous literatures showed that during callogenesis process there is variation in response of plant species and their affinity towards certain type of auxins or cytokinins to callus formation. For example, Das et al. (2013) compared the effect of NAA, IBA and 2,4D on callogensis from Valeriana jatamansi and the best results were obtained at $0.5 \mathrm{mg}^{-1}$ NAA. Our results were in accordance with a study of Hernandez et al. (2005) who revealed that 2,4-D and NAA were less effective and IBA was the best auxin for callus production when applied in combination with BAP.

Our study revealed that callus culture of Rumex vesicarius produced a considerable amount of flavonoids. Plant growth regulators have been widely used in promoting the biosynthesis of both inducible and constitutive secondary metabolites, including medicinal compounds (Vanisree and Tsay 2004; Verpoorte et al., 2002). The effect of applied growth regulators on production of flavonoids from cotyledonary leaf derived calli was in the same trend of callus biomass. The highest flavonoids contents as well as callus productivity were found in callus cultures induced by different concentrations of IBA. The effect of auxin supplementation on the synthesis of bioactive products apparently may correlate to auxin stability (Das et al., 2013). IBA, as a metabolically stable auxin, exhibited a beneficial influence on the flavonoids production of $\mathrm{R}$. vesicarius callus over the other investigated auxins; 2,4-D and NAA. The concentration and auxin-type dependence of valepotriate content in calli of Valeriana glechomifolia was clearly caused by differences in auxin stability and auxin-induced secondary effects (Bello de Carvalho et al., 2004).

From the aforementioned results of the current study, we can infer that $0.5 \mathrm{mg} \mathrm{l-1} \mathrm{IBA}$ is the most suitable for callus induction and proliferation as well as a remarkable flavonoid accumulation so it was used in the following experiments as the callus establishing medium.

Effect of carbohydrates on callus biomass, flavonoid accumulation and enzyme activity.

To evaluate the effect of sugar type on enhancing growth of $R$. vesicarius callus culture, five different sugars were tested. Results indicated that callus culture of $R$. vesicarius could utilize either sucrose or its degradation products (glucose and fructose) efficiently. Sucrose is considered as a common carbohydrate source for most plant tissue culture media. Sucrose is an important biological reservoir for the two assimilating sugars glucose and fructose. An acidic effect of the culture medium ( $\mathrm{pH}$ 5.8) hydrolyzes this sugar and breaks it 
into glucose and fructose which are assimilable by plant cells (Michel et al., 2008). Glucose and fructose are simply assimilated by callus cells and involved directly in plant physiological processes. In our experiment, delay of growth of culture grown on glucose nourished medium may be attributed to the formation of adventitious roots from callus cells. Glucose could participate as a signaling molecule affecting the root growth and development by interacting with phytohormones (Mishra et al., 2009). Also, the growth of calli was very low on media containing galactose and mannose since they have no remarkable effect as anabolic substances.

Results obtained in the current study indicated that the production of flavonoids from $R$. vesicarius callus culture might be affected by the type of supplemented sugars. Ibrahim and Jaafar (2012) and Amin et al. (2007) suggested that the increase in secondary metabolites content in onion was due to $7 \%$ increase in total soluble sugars which was related to the enhanced polyphenolic production. Fructose showed superiority over the other tested sugars giving the highest flavonoids content, and this accumulation of total flavonoids was associated with a high PAL activity and a low activity of PPO. These results may indicate that fructose might act as signaling molecule regulating division, differentiation and cell metabolism (Rolland et al., 2006). In consistence with our results, Masoumian et al. (2011) reported that over the investigated sugars (sucrose, fructose, glucose, sorbitol and mannitol), fructose scored the maximum value of flavonoid produced in Hydrocotyle bonariensis callus tissues. However, fructose had no significant effect on total phenolics and paclitaxel contents, although inhibiting PPO and enhancing the growth of Taxus brevifolia callus culture (Khosroushahi et al., 2011).

Organogenesis (formation of adventitious roots) negatively affects the callus growth in case of glucose treated callus. Also, we assume that the decrease in secondary metabolites is attributed to formation of adventitious roots in callus tissue grown on glucose supplemented medium which revealed a low flavonoid content, in spite of a high activity of PAL and low activity of both PPO and POX. Baque et al. (2010) believed that lower secondary product formation might be due to formation of calluses with adventitious roots. Moreover, it is possible that phenolic compounds produced due to the activity of PAL contributed in other biosynthetic pathways not involved in formation of flavonoid.

Effect of antioxidants on callus biomass, browning intensity and flavonoid accumulation.

Browning greatly affects the growth and sustainability of tissue culture, particularly during the production of secondary metabolites. Wu and Lin (2002) clarified that tissue browning involves the production of many toxic compounds through the phenolization process eventually resulting in the necrosis of cells. Browning phenomenon may include the action of Phenylalanine ammonia lyase, polyphenol oxidase and peroxidase which are the key factors in the biosynthetic pathway of phenylpropanoids and oxidation of phenolics accompanied by pigment accumulation (Tomas-Barberan et al., 1997 and Ahmad et al., 2013).

Egypt. J. Bot., 56, No. 3 (2016) 
In our experiment, the obtained calli quickly turned to dark brown. The addition of a compound with antioxidant activity to the medium helps in minimizing or fixing such a problem. Citric acid largely reduced the callus browning followed by sodium thiosulfate and PVP. It was suggested that appropriate antioxidants could change the cellular redox potentials which would inhibit the oxidation of phenols and delay browning (Pizzocaro et al., 1993). In the same regard, citric acid can delay browning reactions of fresh-cut mangoes during storage (Chiumarelli et al., 2010). Citric acid reduced tissue browning through lowering $\mathrm{pH}$ of tissue or chelating to the copper moiety of PPO (Verma and Joshi, 2000).

Previous investigations revealed no significant correlation between browning and total phenolics accumulation, PPO and POX activities (Cantos et al., 2002 and Khosroushahi et al., 2011). However, our results showed that citric acid caused a retardation of PPO activity, callus browning and pronounced enhancement of total flavonoids content. This is in agreement with a previous study of Zhou et al. (2010) who found that citric acid significantly inhibited PPO activity and stimulated saponin production from Nigella glandulifera callus culture. Much higher PPO activity and rate of phenolics production in Panax ginseng cell cultures were in association with enzymatic browning ( $\mathrm{Wu}$ and $\mathrm{Lin}$, 2002). Similarly, PPO activity was notably reduced by citric acid treatment and accordingly remarkable decrease was observed in the skin browning of santol fruit (Benjawan and Chutichudet, 2009). Other reports have clarified that use of external additives such as citric acid and ascorbic acid has a positive effect in enhancing polyphenol content and related antioxidant activity (Sagwan et al., 2011). Neverthless, citric acid supplementation to culture media resulted in augmentation of total phenolics, but failed to control the browning phenomenon (Khosroushahi et al., 2011).

In the current investigation, PVP promoted PAL activity and the total flavonoids content. PVP is known as a phenolic-specific adsorbent, acts as a protective agent for oxidation of phenolic material and results in lowering callus browning. However, data indicated that PVP enhanced PPO and POX activity and was non-efficient in protecting $R$. vesicarius callus from browning. Our result is similar to that reported by Loredo-Carrillo et al. (2013) who found that the effect of PVP alone on reducing callus browning was less than in a mixture with citric acid or ascorbic acid.

\section{Conclusion}

Callus growth and flavonoid production significantly varied among the investigated types of explants and growth regulators. Cotyledonary leaf explant was better responsive in callus induction and proliferation than hypocotyl one. 
Indole butyric acid showed the superiority over NAA and 2,4-D, resulting in the highest callus biomass and flavonoid accumulation. Among the investigated sugars, sucrose and fructose gave the best callus biomass. However, fructose induced higher total flavonoids content in comparison with the other investigated sugars. Callus browning and polyphenol oxidase activity was greatly reduced by treatment with citric acid and simultaneously high accumulation of total flavonoids was recorded.

\section{References}

Ahmad, I., Hussain, T., Ashraf. I., Nafees, M., Maryam, Rafay, M. and Iqbal, M. (2013) Lethal effects of secondary metabolites on plant tissue culture. AmericanEurasian J. Agric. Environ. Sci., 13, 539-547.

Amin, A.A., Rashad, M. and El-Abagy, H.M.H. (2007) Physiological effects of indole3-butyric-acid and salicylic acid on growth, yield and chemical constituents of onion plants. J. Appl. Sci. Res., 3, 1554-1563.

Anthony, J.M., Senaratna, T., Dixon, K.W. and Sivasithamparam, K. (2004) The role of antioxidants for initiation of somatic embryos with Conostephium pendulum (Ericaceae). Plant Cell Tiss. Organ Cult., 78, 247-252.

Baque, M.A., Hahn, E.J. and Paek, K.Y. (2010) Growth, secondary metabolites production and antioxidant enzyme response of Morinda citrifolia adventitious root as affected by auxin and cytokinin. Plant Biotechnol. Rep., 4, 109-116.

Bello de Carvalho, C.M., Maurmann, N., Luz, D.I., Fett-Neto, A.G. and Rech, S.B. (2004) Control of development and valepotriate production by auxins in micropropagated Valeriana gluchomifolia. Plant Cell Rep., 23, 251-255.

Benjawan, C. and Chutichudet, P. (2009) Control of skin colour and polyphenol oxidase activity in santol fruit by dipping in organic acid solution. Pak. J. Biol. Sci., 12, 852-858.

Bradford, M.M. (1976) A rapid and sensitive method for the quantitation of microgram quantities of protein utilizing the principle of protein-dye binding. Anal Biochem. 72, 248-254.

Cantos, E., Tudela, J.A., Gil, M.I. and Espin, J.C. (2002) Phenolic compounds and related enzymes are not rate-limiting in browning development of fresh-cut potatoes. J. Agric. Food Chem., 50, 3015-3023.

Catapan, E., Busi da Silva, M.L., Netto Moreno, F. and Viana, A.M. (2002) Micropropagation, callus and root culture of Phyllanthus urinaria (Euphorbiaceae). Plant Cell Tiss. Organ Cult., 70, 301-309.

Cheng, G.W. and Breen, P.J. (1991) Activity of phenylalanine ammonia-lyase (PAL) and concentrations of anthocyanins and phenolics in developing strawberry fruit. $J$. Amer. Soc. Hort. Sci., 116, 865-869. 
Chiumarelli, M., Pereira, L.M., Ferrari, C.C., Sarantopoulos, C.I.G.L. and Hubinger, M.D. (2010) Cassava starch coating and citric acid to preserve quality parameters of fresh-cut "tommy atkins" mango. J. Food Sci., 75, 297-304.

Das, J., Mao, A.A. and Handique, P.J. (2013) Callus-mediated organogenesis and effect of growth regulators on production of different valepotriates in Indian valerian (Valeriana jatamansi Jones.) Acta Physiol. Plant., 35, 55-63.

Gaspar, T., Kevers, C., Penel, C., Greppin, H., Reid, D.M. and Thorpe, T.A. (1996) Plant hormones and plant growth regulators in plant tissue culture. In vitro cell Dev. Biol.-Plant., 32, 272-289.

Giridhar, P., Kumar, V. and Ravishankar, G.A. (2004) Somatic embryogenesis, organogensis, and regeneration from leaf callus culture of Decalepis hamiltonii wight and arn., an endangered shrub. in vitro cell Dev. Biol.-Plant., 40, 567-571.

Hammerschmidt, R. (1999) Phytoalexins: what have we learned after 60 years? Annu. Rev. Phytopathol., 37, 285-306.

Heath, M.C. (1980) Reaction of nonsuscepts to fungal pathogens. Annu. Rev. Phytopathol., 18, 211-236.

Hernandez, X.E., Orden, A.A. and Giordano, O.S. (2005) Effects of elicitor and copper sulfate on grindelic acid production in submerged cultures of Grindelia pulchella. Electron. J. Biotechnol. 8(3) DOI: 10.2225/vol8-issue3-fulltext-6 .

Ibrahim, M.H. and Jaafar, H.Z.E. (2012) Impact of elevated carbon dioxide on primary, secondary metabolites and antioxidant responses of Eleais guineensis Jacq. (Oil palm) seedlings. Molecules, 17, 5195-5211.

Ikenaga, T., Handayani, R. and Oyama, T. (2000) Steroidal saponin production in callus cultures of Solanum aculeatissimum Jacq. Plant Cell Rep., 19, 1240-1244.

Jain, S.C., Pancholia, B. and Jain, R. (2012) In-vitro callus propagation and secondary metabolite quantification in Sericostoma pauciflorum. Iran J. Pharm. Res., 11, 11031109.

Kar, M. and Mishra, D. (1976) Catalase, peroxidase and Polyphenoloxidase activities during rice leaf senescences. Plant Physiol., 57, 315-319.

Karam, N.S., Jawad, F.M., Arikat, N.A. and Shibli, R.A. (2003) Growth and rosmarinic acid accumulation in callus, cell suspension and root cultures of wild Salvia fruticosa. plant cell tiss. organ cult., 73, 117-121.

Khosroushahi, A.Y., Naderi-Manesh, H. and Simonsen, H.T. (2011) Effect of antioxidants and carbohydrates in callus cultures of Taxus brevifolia: evaluation of browning, callus growth, total phenolics and paclitaxel production. Bio Impacts BI 1, 37. 
Loredo-Carrillo, S.E., Santos-Diaz, M.L., Leyva, E. and Santos-Diaz, M.S. (2013) Establishment of callus from Pyrostegia venusta (Ker Gawl.) Miers and effect of abiotic stress on flavonoids and sterols accumulation. J. Plant Biochem. Biot., 22, 312-318.

Maheshwari, P.1., Songara, B., Kumar, S., Jain, P., Srivastava, K. and Kumar, A. (2007) Alkaloid production in Vernonia cinerea: Callus, cell suspension and root cultures. Biotechnol. J., 2, 1026-1032.

Masoumian, M., Arbakariya, A., Syahida, A. and Maziah, M. (2011) Flavonoids production in Hydrocotyle bonariensis callus tissues. J. Med. Plants Res., 5, 15641574.

Mathews, H. (1987) Morphogenetic responses from in vitro cultured seedling explants of mung bean (Vigna radiata L. Wilczek). Plant Cell Tiss. Organ Cult., 11, 233-240.

Mayer, A.M. and Harel, E. (1979) Polyphenol oxidases in plants. Phytochemistry, 18, 193-215.

Michel, Z., Hilaire, K.T., Mongomake, K., Georges, A.N. and Yustin, K.Y. (2008) Effect of genotype, explants, growth regulators and sugars on callus induction in cotton (Gossypium hirsutum L.). Aust. J. Crop Sci., 2, 1-9.

Mishra, B.S., Singh, M., Aggrawal, P. and Laxmi, A. (2009) Glucose and auxins signaling interaction in Arabidopsis thaliana seedling root growth and development. Plos One, 4:e4502 DOI:10.1371/journal.pone.0004502.

Morkunas, I., Marczak, L., Stachowiak, J. and Stobiecki, M. (2005) Sucrose induced lupine defense against Fusarium oxysporum: Sucrose-stimulated accumulation of isoflavonoids as a defense response of lupine to Fusarium oxysporum. Plant Physiol. Biochem., 43, 363-373.

Murashige, T. and Skoog, F. (1962) A revised medium for rapid growth and bioassays with tobacco tissue cultures. Physiol. Plant., 15, 473-497.

Ndakidemi, C.F., Mneney, E. and Ndakidemi, P.A. (2014) Effects of ascorbic acid in controlling lethal browning in in vitro culture of Brahylaena huillensis using nodal segments. Am. J. Plant Sci., 5, 187-191.

Pandey, G. and Madhuri, S. (2010) pharmacological activities of Ocimum sanctum (tulsi): a review. Int. J. Pharm. Sci. Rev. Res., 5, 61-65.

Pasqua, G., Avato, P., Monacelli, B., Santamaria, A.T. and Argentieri, M.P. (2003) Metabolites in cell suspension cultures, calli, and in vitro regenerated organs of Hypericum perforatum cv. Topas. Plant Sci., 195, 977-982.

Pizzocaro, F., Torreggiani, D. and Gilardi, G. (1993) Inhibition of apple polyphenol oxidase (PPO) by ascorbic acid, citric acid and sodium chloride. J. Food Process. Preserv., 17, 21-30.

Rolland, F., Baena-Gonzalez, E. and Sheen, J. (2006) Sugar sensing and signaling in plants: conserved and novel mechanisms. Annu. Rev. Plant Biol., 57, 675-709.

Egypt. J. Bot., 56, No. 3 (2016) 
Sagwan, S., Rao, D.V. and Sharma, R.A. (2011) In vitro and In vivo antioxidant activity and total phenolic content of Pongamia pinnata (L.) Pierre: an important medicinal plant. Int. J. Biotechnol., 4, 568-574.

Sathyanarayana, B.N. and Varghese, D.B. (2007) "Plant Tissue Culture Practices and New Experimental Protocols”. I.K.International Publishing, India. pp. 240.

Sheen, J., Zhou, L. and Jang, J.C. (1999) Sugars as signaling molecules. Curr. Opin. Plant Biol., 2, 410-418.

Tan, Z., Zhang, Y., Deng, J., Zeng, G. and Zhang, Y. (2012) Purified vitexin compound 1 suppresses tumor growth and induces cell apoptosis in a mouse model of human choriocarcinoma. Int. J. Gynecol. cancer, 22, 360-366.

Toma's-Barbera'n, F.A., Gil, M.I., Castan ${ }^{\sim}$ er, M., Arte's, F. and Saltveit, M.E. (1997) Effect of selected browning inhibitors on phenolic metabolism in stem tissue of harvested lettuce. J. Agric. Food Chem., 45, 583-589.

Vanisree, M. and Tsay, H.S. (2004) Plant cell cultures-an alternative and efficient source for the production of biologically important secondary metabolites. Int. J. Appl. Sci. Eng., 2, 29-48.

Verma, L.R. and Joshi, V.K. (2000) Postharvest technology of fruits, handling, Processing, Fermentation and Waste Management. Indus publishing company, New Delhi. Vol 2, pp. 174.

Verpoorte, R., Contin, A. and Memelink, J. (2002) Biotechnology for the production of plant secondary metabolites. Phytochem. Rev., 1, 13-25.

Wang, J., Xiao, X., Wang, Q., Li, X., Zhang, L. and Li, J. (2013) Accumulation of flavonoids and antioxidant activity of Stellera chamaejasme by an efficient callus culture. Hort. Environ. Biotechnol., 54, 441-449.

Wang, X.D., Nolan, K.E., Irwanto, R.R., Sheahan, M.B. and Rose, R.J. (2011) Ontogeny of embryogenic callus in Medicago truncatula: the fate of the pluripotent and totipotent stem cells. Ann. Bot., 107, 599-609.

Wu, J. and Lin, L. (2002) Ultrasound-induced stress responses of Panax ginseng cells: enzymatic browning and phenolics production. Biotechnol. Progr., 18, 862-866.

Yan, M., Xu, C., Chun-Hwan, K., Yeong-Cheol, U., Amadou, A.B. and De-Ping, G. (2009) Effects of explant type, culture media and growth regulators on callus induction and plant regeneration of Chinese jiaotou (Allium chinense). Sci. Hortic., 123, 124-128.

Zhishen, J., Mengcheng, T. and Jianming, W. (1999) Research on antioxidant activity of flavonoids from natural materials. Food Chem., 64, 555-559. 
Zhou, B., Wei, X., Wang, R. and Jia, J. (2010) Quantification of the enzymatic browning and secondary metabolites in the callus culture system of Nigella glandulifera Freyn \& Sint. Asian J. Tradit. Med., 5, 109-116.

Zucker, M. (1969) Induction of phenylalanine ammonia-lyase in Xanthium leaf disks. Photosynthetic requirement and effect of day length. Plant Physiol., 44, 912-922.

(Received 29/12/2015; accepted $1 / 2 / 2016)$

\title{
تأثير منظمات النمو والكربوهيدرات ومضادات الأكسده على النمو

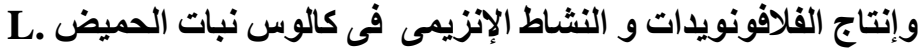 .Rumex vesicarius
}

\author{
نادية محمد الثافعى، إيناس شعبان أحمد، منى سيد ، علا حموده وصلاح الدين

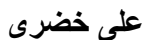$$
\text { قسم النبات و الميكروبيولوجى - كلية العلوم - جامعة بنى سويفـ بنى سويف ـ }
$$ \\ تهدف الدراسة الحالية الى التحقق من تأثير منظمات النمو و الكربو هيدرات

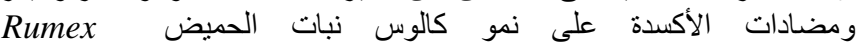 \\ vesicarius

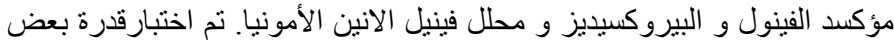

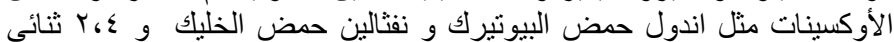

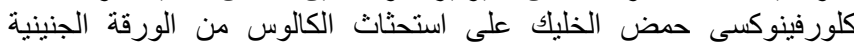

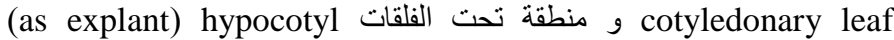

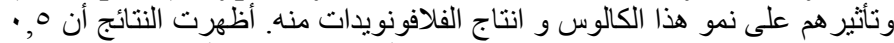

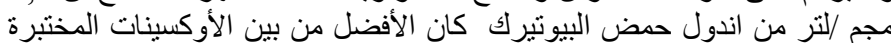

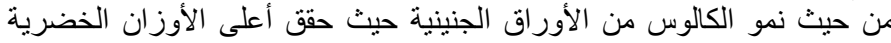

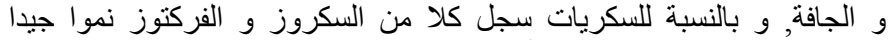

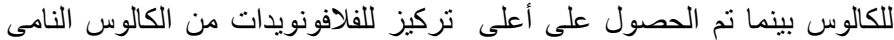

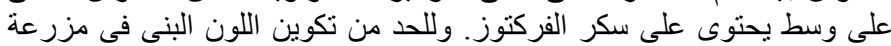

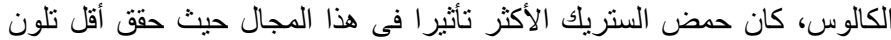

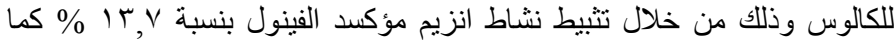

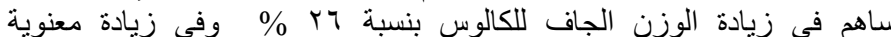

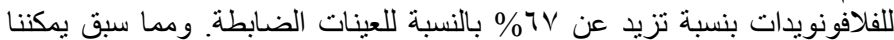

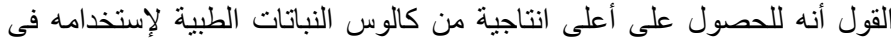

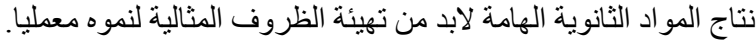


EFFECT OF GROWTH REGULATORS, CARBOHYDRATES ... 